\title{
Selection of Aluminum-Resistant Wheat Genotypes Using Multienvironment and Multivariate Indices
}

\author{
Jorge González Aguilera, Paulo Eduardo Teodoro,* \\ José Pereira da Silva Junior, Jorge Fernando Pereira, Alan Mario Zuffo, and Luciano Consoli
}

\begin{abstract}
A gain in association was obtained by using a new multivariate index with alleles of TaALMT1 and TaMATE1B genes compared with a previously published index. Wheat is among the major grain crops. Its growth can be affected by aluminum toxicity, an important stress factor that limits plant productivity. Thus, an efficient means to select wheat genotypes that are resistant to this stress is required. Here, 172 wheat cultivars and 23 synthetic hexaploid wheat plants showing different alleles for TaALMT1 and TaMATE1B and different levels of $\mathrm{Al}$ resistance in field conditions (phenotyped in two crop seasons) were studied. The modified Lin and Binns method was applied to obtain the phenotype data in a multivariate manner aiming at a general identification of genotypes based on the multiple traits evaluated. The genotype $\times$ year interaction was significant for all traits that were evaluated in three growth stages (tillering, silking, and maturation). The top $20 \mathrm{Al}$-resistant genotypes obtained by the multivariate method were highlighted as having the best combination of the main desirable traits. Correlation analysis showed a gain in the association of the multivariate index with alleles of TaALMT1 and TaMATE1B genes compared with a previously published index. The superior TaMATE1B allele (having an insertion in the promoter region) contributed a greater $\mathrm{Al}$ resistance independent of the TaALMT1 allele. The higher association with $\mathrm{Al}$ resistance qualifies the selection index described in this study to be used for wheat breeding programs with the aim of improving the performance of wheat when grown under Al stress.
\end{abstract}

\section{Core Ideas}

- Wheat is among the major grain crops.

- Its growth can be affected by aluminum toxicity.

- Genotypes with high adaptability and stability were identified.

- A new multivariate index allowed greater association with $\mathrm{Al}$ resistance.

Published in Agron. J. 111:1-7 (2019)

doi:10.2134/agronj2019.06.0470

Supplemental material available online

Copyright $(2019$ The author(s). Re-use requires permission from the publisher.
B RAZIL IS one of the major importers of wheat (Triticum aestivum L.) in the world. To increase food security, Brazil needs to increase its wheat production. However, the area dedicated to wheat cultivation in Brazil has remained virtually the same (around $2500 \mathrm{ha}$ ) for the past $10 \mathrm{yr}$ (CONAB, 2018). Based on this, greater wheat production will have to come from increased productivity and not by increasing the cultivated area. This is the same globally because the primary mechanism of increasing food production in the world in the next $30 \mathrm{yr}$ will need to rely on yield increase (Fischer et al., 2014).

Greater wheat production can be achieved by better cultivars and management practices. For instance, in the Cerrado region of Brazil, the increase of $37 \mathrm{~kg}$ of wheat produced per hectare per year is $47.4 \%$ due to improvements in management practices and 52.6\% due to better cultivars (Cargnin et al., 2009). Nevertheless, most of the significant future improvements in wheat production will probably come from better cultivars. When focusing on breeding programs, the identification of lineages showing superior performance is one of the biggest challenges. The selection process is often based on the performance of the genotypes in different environments (years and/ or locations). However, the decision to launch new cultivars is usually hampered by the frequent occurrence of genotype and its interactions with the environment (Cargnin et al., 2006). For this purpose, adaptability and stability analyses are performed, through which it is possible to identify cultivars that are adaptable to specific environments or that exhibit broad adaptability. Several methods of adaptability and stability analyses have been described for the evaluation of genetic materials (Cruz and Carneiro, 2003). Among these, we highlighted the methodology of Lin and Binns (1988), where the $P_{i}$ parameter is estimated based on the mean square of the distance between the genotype mean and the maximum average response obtained in the environment. This parameter has variance property and measures the response of a genotype to the best genotype in each environment. This method has been used by several researchers because it is based on nonparametric statistics. Therefore, it can be applied to various environments and genotypes. In addition, the recommendation of this method is based on a single-step

J.G. Aguilera, P.E. Teodoro, A.M. Zuffo, Univ. Federal de Mato Grosso do Sul- Campus de Chapadão do Sul, Rodovia MS 306 km 105, Chapadão do Sul, MS, CEP 79560-000, Brazil; J.P. da Silva Junior, L. Consoli, Embrapa Trigo, Rodovia BR 285 km 294, Passo Fundo, RS, CEP 99001-970, Brazil; J.F. Pereira, Embrapa Gado de Leite, Rua Eugênio do Nascimento 610, Juiz de Fora, MG, CEP 36038-330, Brazil. Received 21 June 2019. Accepted 14 July 2019. *Corresponding author (eduteodoro@hotmail.com).

Abbreviations: CIATF, classification index of aluminum toxicity in the field; OA, organic acid; SHW, synthetic hexaploid wheat. 
analysis that is not obtained in other methods, such as the method in Eberhart and Russell (1966), which uses an environmental index and parameters linked to the regression equation.

Although the $P_{\mathrm{i}}$ parameter selection index has been used for multiple traits in multiple environments to select wheat genotypes (Albrecht et al., 2007; Biudes et al., 2009; Cargnin et al., 2008; Caierão et al., 2006; Franceschi et al., 2010; Murakami et al., 2004), it has not been used to select wheat materials that show superior resistance to aluminum (Al). There is interest in applying this index in the selection of Al-resistant wheat genotypes because Al toxicity is found in acidic soils, which is one of the major factors limiting wheat production worldwide. In acidic soils, the toxic trivalent $\mathrm{Al}$ cation becomes prevalent, impacting elongation and division of the root cells, which results in plants with lower root growth (Kochian et al., 2015). Shorter roots may affect plant development and enhance the probability of nutritional, drought, and heat stresses. The chances of wheat plants facing $\mathrm{Al}$ toxicity are high because acidic soils constitute $\sim 60 \%$ of the area in the tropical and subtropical regions (von Uexküll and Mutert, 1995) and constitute a similar proportion in the Brazilian territory (FAO, 2000).

Among the mechanisms by which plants cope with $\mathrm{Al}$ toxicity, organic acid (OA) efflux is highlighted in many crop species (Yang et al., 2019). In wheat, the genes TaALMT1 and TaMATE1B, which code malate and citrate transporters, respectively, are responsible for OA efflux at the root tips (Sasaki et al., 2004; Tovkach et al., 2013). The alleles of TaALMT1 and TaMATE1B differ in the promoter regions. Alleles I to VII contrasts in number of tandem repeats in the TaALMT1, and alleles $(+)$ or $(-)$ vary with the presence or absence of an upstream insertion in TaMATE1B (Garcia-Oliveira et al., 2014; Raman et al., 2008; Sasaki et al., 2006; Tovkach et al., 2013). Wheat haplotypes with superior alleles (V+ or VI+) usually show higher expression level of those genes, which are associated with greater OA efflux and, consequently, improved root growth. The impact of TaALMT1 and TaMATE1B alleles has been studied in hydroponics (Garcia-Oliveira et al., 2014; Han et al., 2013, 2016; Raman et al., 2008; Sasaki et al., 2006) and in field conditions (Aguilera et al., 2016).

Studies evaluating $\mathrm{Al}$ resistance in field conditions are more realistic than those in controlled environments, and the analysis of field data results in the possibility of selecting Al-resistant genotypes in a more precise way. de Sousa et al. (1984) proposed a method of classification index of aluminum toxicity in the field (CIATF), where visual scores are given to wheat plants in three growth stages (tillering, silking, and maturation) based on the comparison with Al-resistant and Al-sensitive controls. This method was modified by de Sousa (1998) and based on the CIATF, wheat genotypes can be discriminated as Al-resistant, Al-moderately resistant, Al-moderately susceptible, and Al-susceptible. This method has previously been used by our group (Aguilera et al., 2016); however, it is unknown if other selection indexes, such as a $P_{\mathrm{i}}$ parameter-based selection index, can be more effective in discriminating $\mathrm{Al}$ resistance in field conditions. In this context, this work aims at using a selection index based on the $P_{\mathrm{i}}$ parameter to improve the selection of wheat cultivars that are resistant to $\mathrm{Al}$ and to evaluate the correlation between the allelic variability of TaALMT1 and TaMATE1B genes with the $\mathrm{Al}$ resistance phenotype in field conditions.

\section{MATERIALS AND METHODS}

Plant Material

The phenotype and genotype information of wheat (including commercial cultivars, cultivars, synthetic wheat, and lineages) with contrasting levels of Al resistance (Supplementary Table S1), previously published by Aguilera et al. (2016), were used in the present study. We focused on a set of 172 genotypes that were selected to represent both Brazilian and foreign genotypes in approximately the same proportion ( 90 Brazilian genotypes and 82 genotypes from other countries), and we analyzed 23 synthetic hexaploid wheat (SHW) genotypes. All genotypes were evaluated in field conditions with three replicates. Among these genotypes, the cultivars IAC 5-Maringá and Anahuac 75 were considered Al-resistant and Al-sensitive controls, respectively.

\section{Al Resistance in the Field}

The Al resistance of 195 wheat genotypes, which was evaluated in field conditions at Embrapa Trigo's experimental field $\left(28^{\circ} 15^{\prime} \mathrm{S}, 52^{\circ} 24^{\prime} \mathrm{W}\right)$ during two growing seasons (2012 and 2013), was obtained by Aguilera et al. (2016). Phenotyping was performed in the soil classified as Haplorthox, containing 45\% clay. The soil $\mathrm{pH}$ ranged from 4.3 to 4.7 , and the soil contained 29 to $54 \mathrm{mmol} \mathrm{dm}^{-3} \mathrm{Al}^{3+}$ throughout the 2 -yr duration of the test. A randomized complete block design was performed where plots consisted of six rows (containing five different genotypes and one of the controls placed alternately) of $3 \mathrm{~m}$ length with three replications. The plants were evaluated at three developmental stages (tillering, silking, and maturation), and a CIATF was calculated based on the scores (Aguilera et al., 2016). The CIATF states that genotypes with the score of 0.05 to 1.25 are resistant, 1.26 to 2.5 are moderately resistant, 2.51 to 3.75 are moderately susceptible, and 3.76 to 5.00 are susceptible.

\section{Alleles of the TaAMLTI and TaMATEIB Genes}

Information about the TaALMT1 and TaMATE1B promoter alleles was based on previous results (Aguilera et al., 2016) and is presented in Supplementary Table S1. TaALMT1 alleles can be detected using primers LPF-F (CCTGGTTTTCTTGATGGGGGCACA), LPF-R (TGCCCACCATCTCGCCGTCGCTCTCTCT), SPF-F (GCTCCTACCACTATGGTTGCG), and SPF-R (CCAGGCCGACTTTGAGCGAG) according to amplification protocols described previously (Raman et al., 2008; Sasaki et al., 2006). TaMATE1B alleles can be discriminated by the presence or absence of the polymerase chain reaction product obtained from primers TaMATE1-4B-SLT-F (ATCCATCCTCCTTCCCTCAC) and TaMATE1-4B-SLT-R (ATGAATGCTGTGTCCACCAA) and by the amplification protocol described previously (Garcia-Oliveira et al., 2014).

\section{Statistical Analyses}

We performed individual ANOVA for each environment (year), followed by analysis of joint variance according to the statistical model described in Eq. [1]:

$$
Y_{i j k}=\mathrm{m}+B / E_{j k}+G_{i}+E_{j}+\left(\mathrm{G} \times E_{i j}\right)+\varepsilon_{i j k}
$$


Table I. Analysis of joint variance for the variable aluminum resistance observed in tillering, silking, and maturation among 195 wheat genotypes.

\begin{tabular}{lcccc}
\hline \multirow{2}{*}{$\begin{array}{l}\text { Source of } \\
\text { variation }\end{array}$} & $\begin{array}{c}\text { Degrees of } \\
\text { freedom }\end{array}$ & \multicolumn{3}{c}{ Mean square } \\
\cline { 3 - 5 } Blocks/years & 4 & Tillering & Silking & Maturation \\
Genotype (G) & 194 & 3.79 & 3.69 & 2.88 \\
Year $(Y)$ & $\mathrm{I}$ & $7018^{*}$ & $6.26^{*}$ & $9.43^{*}$ \\
$\mathrm{G} \times \mathrm{Y}$ & 194 & $0.43^{*}$ & $0.72^{*}$ & $137.26^{*}$ \\
Residue & 776 & 0.35 & 0.30 & $0.91^{*}$ \\
$\mathrm{CV}, \%$ & & 18.82 & 16.35 & 21.47 \\
Overall average & & 3.14 & 3.34 & 3.21 \\
\hline
\end{tabular}

* Significant at the 0.05 probability level.

where $Y_{i j k}$ is the observation of the $k$ th block evaluated in the $i$ th genotype and $j$ th year, $\mu$ is the overall mean of the experiments, $B / E_{j k}$ is the effect of block $k$ within year $j, G_{i}$ is the effect of the $i$ th genotype considered as random, $E_{j}$ is the effect of the $j$ th year considered as fixed, $G \times E_{i j}$ is the random effect of the interaction between genotype $i$ and environment $j$, and $\varepsilon_{i j k}$ is the random error associated with $Y_{i j k}$ observation. After that, the estimate of adaptability and stability $\left(P_{\mathrm{i}}\right)$ for each character proposed by Lin and Binns (1988) was calculated according to Eq. [2]:

$$
P_{i}=\frac{\sum_{j=1}^{e}\left(Y_{i j}-Y_{m j}\right)^{2}}{2 e}
$$

where $Y_{i j}$ is the score of the $i$ th genotype in the $j$ th year, $Y_{m j}$ is the estimate of the ideal hypothetical genotype in year $j$, and $e$ is the number of years. For the selection of genotypes with higher $\mathrm{Al}$ resistance considering the scores at the different growth stages (tillering, silking, and maturation) and the $2 \mathrm{yr}$ of evaluation, the multivariate statistic $P_{\text {im }}$ was used, according to Eq. [3]:

$$
P_{\mathrm{im}}=\sum_{k=1}^{v}\left[\frac{P_{i k}}{\hat{\sigma}_{P_{i k}}}\right]
$$

where $P_{i k}$ is the univariate estimator of the adaptability and stability of the $i$ th genotype associated with the $k$ th variable, and $\hat{\sigma}_{P_{i k}}$ is the standard deviation of $P_{i k}$. After the selection of the genotypes with lower values of $P_{\text {im }}$, the estimates of the genetic gains (GS) for each character and year were obtained, according to Eq. [4]:

$$
\mathrm{GS}_{(\%)}=\frac{\left(X_{\mathrm{s}}-X_{\mathrm{o}}\right) \times h^{2}}{X_{\mathrm{o}}}
$$

where $X_{\mathrm{s}}$ is the 20 genotypes selected, $X_{\mathrm{o}}$ is the original character average, and $h^{2}$ is the broad heritability of character. Data of $P_{\text {im }}$, CIATF, and the different TaALMT1 and TaMATE1B alleles and the combinations of alleles (haplotypes) were used in the correlation analysis using the GENES program (Cruz, 2013). The selection of the best genotypes was performed using the multivariate index $P_{\mathrm{im}}$. All analyses were performed using Genes software (Cruz, 2013).

\section{RESULTS}

\section{Variance for Al Resistance in Field Conditions}

The $\mathrm{Al}$ resistance of the wheat genotypes studied here was evaluated previously (Aguilera et al., 2016) based on visual characteristics observed in the three different growth stages
Table 2. Estimates of the original mean $\left(X_{0}\right)$, mean of the selected $\left(X_{s}\right)$ genotype, selection differential, broad heritability, and selec-

\begin{tabular}{|c|c|c|c|c|c|c|}
\hline Phases & Year & $x_{0}$ & $X_{s}$ & $\begin{array}{l}\text { Selection } \\
\text { differential }\end{array}$ & Heritability & $\begin{array}{l}\text { Selection } \\
\text { gain }\end{array}$ \\
\hline & & & & & & \\
\hline \multirow[t]{2}{*}{ Tillering } & I & 3.39 & 2.27 & -1.12 & 81.54 & -26.94 \\
\hline & 2 & 2.90 & 1.69 & -1.21 & 77.95 & -32.52 \\
\hline \multirow[t]{2}{*}{ Silking } & I & 3.82 & 1.53 & -2.29 & 91.41 & -54.80 \\
\hline & 2 & 2.87 & 1.41 & -1.46 & 91.50 & -46.55 \\
\hline \multirow[t]{2}{*}{ Maturation } & I & 3.55 & 1.21 & -2.34 & 89.50 & -58.99 \\
\hline & 2 & 2.86 & 0.97 & -1.89 & 92.52 & -61.14 \\
\hline
\end{tabular}
tion gain based on the multivariate $P_{\mathrm{i}}\left(P_{\mathrm{im}}\right)$ statistics of the genotypes with the highest $\mathrm{Al}$ resistance (lower grades).

(tillering, silking, and maturation) of the wheat plants grown in acidic soil in two successive growing seasons. The mean scores for each growth stage of the 195 wheat genotypes are shown in the Supplementary Table S1. Based on these scores, an ANOVA was performed, and significant differences $(P<0.05)$ were obtained for the genotypes, years, and their interaction (genotype $\times$ year). This shows high diversity of responses among the genotypes (Table 1). The coefficients of phenotypic variation, which are indicative of the experimental precision, exhibited values $<22 \%$, showing high homogeneity of the data obtained in the experimental conditions (Table 1).

\section{Genetic Estimators Associated with $\boldsymbol{P}_{\text {im }}$ in the Selection of Al-Resistant Genotypes}

The average of the scores for $\mathrm{Al}$ resistance allowed the estimation of the $P_{\mathrm{i}}$ index, as proposed by Lin and Binns (1988), for the wheat genotypes. With these values in each of the growth stages, $P_{\text {im }}$ was obtained, which allowed the estimation of the original mean, the mean of the selected genotype, selection differential, heritability, and selection gain for both years of evaluation (Table 2). Average reductions of more than 34, 52 , and $67 \%$ for tillering, silking, and maturation, respectively, were observed. The observation was independent of the phase and the year sampled when applying a selection intensity of $9.5 \%$ (the best 20 genotypes). These results showed that $\mathrm{Al}$ resistance becomes more evident as the plants grow. The selection differential also showed this behavior (Table 2). For the traits evaluated, the heritability values were $>78 \%$, which indicate the possibility of gains, with the selection of this characteristic being of 27 to $61 \%$, depending on the stage at which the selection was performed, being superior in maturation stage.

The $P_{\text {im }}$ index allowed the selection of the top best 20 genotypes considering their performance in both years and in all different growth stages (Table 3 ). The ranking of $P_{\text {im }}$ values confirmed the genotypes that were widely recognized as $\mathrm{Al}$ resistant (Toropi, Trintecinco, BH 1146, IAC 5-Maringá, and Giza 121) and as the best five genotypes among the top 20 genotypes, with values from 0.00 to 0.29 . This shows their superiority in $\mathrm{Al}$ resistance in acidic soil in field conditions. Of the 20 selected genotypes, 15 were obtained from Brazil, which shows the great potential of the Brazilian wheat germplasm to resist $\mathrm{Al}$ if we consider the balance between the number of genotypes selected from Brazil ( 90 genotypes) and that from other parts of the world (82 genotypes). Most Brazilian genotypes have both Pollyssú and Alfredo Chaves lines in their genealogy, with the exception of Trintecinco and PG 1, which have only 
Table 3. Evaluation of aluminum resistance of the top 20 wheat genotypes.

\begin{tabular}{|c|c|c|c|c|c|c|c|c|c|c|c|c|c|c|}
\hline \multirow[b]{2}{*}{ Genotype } & \multirow[b]{2}{*}{ Origin } & \multirow{2}{*}{$\begin{array}{l}\text { TaALMTI } \\
\text { allele }\end{array}$} & \multirow{2}{*}{$\begin{array}{l}\text { TaMATEIB } \\
\text { allele }\end{array}$} & \multicolumn{3}{|c|}{ Tillering } & \multicolumn{3}{|c|}{ Silking } & \multicolumn{3}{|c|}{ Maturation } & \multirow[b]{2}{*}{$P_{\text {im }}$} & \multirow[b]{2}{*}{ CIATF $\ddagger$} \\
\hline & & & & Year I & Year 2 & $P_{\mathrm{i}} \dagger$ & Year I & Year 2 & $P_{i}$ & Year I & Year 2 & $P_{i}$ & & \\
\hline Toropi & Brazil & $\mathrm{VI}$ & + & 1.47 & 0.82 & 0.00 & 0.50 & 1.00 & 0.00 & 0.87 & 0.50 & 0.01 & 0.00 & $\mathrm{R}$ \\
\hline Trintecinco & Brazil & $\mathrm{VI}$ & + & 1.65 & 0.99 & 0.03 & 0.48 & 1.03 & 0.00 & 1.05 & 0.50 & 0.02 & 0.03 & $\mathrm{R}$ \\
\hline $\mathrm{BH} I \mathrm{I} 46$ & Brazil & $\mathrm{V}$ & - & 1.54 & 0.79 & 0.01 & 1.95 & 1.26 & 0.56 & I. 17 & 0.65 & 0.06 & 0.25 & $\mathrm{R}$ \\
\hline IAC 5- Maringá & Brazil & $\mathrm{VI}$ & + & 2.10 & 0.93 & 0.14 & 1.56 & 1.21 & 0.30 & 1.34 & 0.94 & 0.17 & 0.27 & MR \\
\hline Giza 121 & Egypt & V & - & 1.38 & 1.35 & 0.08 & I.7I & 1.21 & 0.39 & 1.35 & 1.13 & 0.24 & 0.29 & $M R$ \\
\hline PG I & Brazil & VI & + & 1.88 & 1.82 & 0.33 & 0.78 & I.II & 0.03 & 0.84 & 1.08 & 0.16 & 0.30 & $\mathrm{R}$ \\
\hline Jesuita & Brazil & $\mathrm{VI}$ & + & 1.48 & 2.00 & 0.37 & 1.28 & 1.05 & 0.16 & 1.00 & 0.75 & 0.06 & 0.35 & $M R$ \\
\hline Klein Lucero & Argentina & VI & + & 2.04 & 2.21 & 0.61 & 0.77 & 1.21 & 0.03 & 1.00 & 0.91 & 0.10 & 0.48 & MR \\
\hline Trigo BR 35 & Brazil & $\mathrm{VI}$ & - & 2.54 & 1.37 & 0.42 & 2.28 & 1.34 & 0.84 & 1.00 & 1.10 & 0.17 & 0.69 & $M R$ \\
\hline BRS 49 & Brazil & V & - & 2.38 & 1.99 & 0.61 & I.78 & 1.75 & 0.57 & 1.55 & 1.12 & 0.30 & 0.76 & $M R$ \\
\hline Menceki & Turkey & V & - & $2.7 \mathrm{I}$ & 1.82 & $0.7 \mathrm{I}$ & 2.07 & 1.23 & 0.65 & 1.34 & 0.29 & 0.06 & 0.78 & $M R$ \\
\hline Trigo BR 32 & Brazil & $\mathrm{V}$ & - & $2.7 \mathrm{I}$ & 1.90 & 0.75 & 1.95 & 1.37 & 0.58 & 1.00 & 0.95 & 0.12 & 0.80 & $M R$ \\
\hline Colonista & Brazil & VI & + & 2.31 & 2.32 & 0.81 & 1.39 & 1.99 & 0.45 & 1.14 & 1.19 & 0.22 & 0.83 & $M R$ \\
\hline IAS 20-lassul & Brazil & V & - & 2.95 & 1.12 & 0.65 & 2.21 & 1.05 & 0.75 & 1.50 & 0.98 & 0.23 & 0.84 & $M R$ \\
\hline Bet Dagan I3| & Israel & $\mathrm{V}$ & + & 3.04 & 1.66 & 0.88 & 1.78 & 1.46 & 0.48 & 1.34 & 1.00 & 0.19 & 0.88 & MR \\
\hline Colonias & Brazil & $\mathrm{VI}$ & + & 2.80 & 2.16 & 0.97 & 1.38 & 1.98 & 0.44 & 1.13 & 0.87 & 0.10 & 0.90 & MR \\
\hline Emb_92102 & Brazil & $\mathrm{VI}$ & - & 2.54 & 1.82 & 0.61 & 2.44 & 1.45 & I.0I & 1.50 & 1.01 & 0.24 & 0.91 & $M R$ \\
\hline Maya 74 & Guatemala & V & + & 2.71 & 2.16 & 0.91 & 1.77 & 1.55 & 0.49 & 1.00 & 1.41 & 0.32 & 0.95 & MR \\
\hline Emb_90I0I & Brazil & V & - & 3.04 & 1.99 & 1.05 & 1.45 & 1.57 & 0.32 & 1.67 & 1.23 & 0.39 & 1.00 & $\mathrm{MR}$ \\
\hline Frondoso & Brazil & $\mathrm{V}$ & - & 2.04 & 2.58 & 0.91 & 1.01 & 2.33 & 0.52 & 1.50 & 1.80 & 0.68 & 1.08 & MR \\
\hline
\end{tabular}

$\dagger$ Averages of the notes and estimates of $\mathrm{Pi}$ are shown for each of the growth stages (tillering, silking, and maturation). The lowest estimates of multivariate $P_{\mathrm{i}}\left(P_{\mathrm{im}}\right)$ indicate greater $\mathrm{Al}$ resistance.

$\ddagger$ Classification index of aluminum toxicity in the field (MR, moderately resistant; $R$, resistant).

one resistance genotype (Alfredo Chaves or Pollyssú lines) as an ancestor. However, non-Brazilian genotypes (Klein Lucero and Menceki) have different sources of resistance and do not share common ancestors (Supplementary Table S2). The $P_{\text {im }}$ index values for all the wheat genotypes in this study are shown in Supplementary Table S1. Among the evaluated genotypes, Zambezi (Zimbabwe) and Angas (Australia) genotypes matched the behavior of the susceptible control Anhauac 75 (Mexico) and could be used as susceptible controls in future experiments.

\section{Correlations Associated with $P_{\text {im }}$ in the Selection of Al-Resistant Genotypes}

The most important mechanisms of $\mathrm{Al}$ resistance in hexaploid wheat are based on the efflux of malate and citrate anions from the root apices, which is controlled by the TaALMT1 and TaMATE1B genes, respectively (Sasaki et al., 2004; Tovkach et al., 2013). The correlation of the $P_{\text {im }}$ index with malate and citrate transporters associated with the TaALMTI and

Table 4. Pearson correlation, obtained by multivariate $P_{\mathrm{i}}\left(P_{\mathrm{im}}\right)$ index, with the promoters TaALMTI and TaMATEIB and the Al resistance of 195 wheat genotypes cultivated in acidic soil in field conditions. The correlation of the classification index of aluminum toxicity in the field (CIATF), obtained previously (Aguilera et al. 2016), is shown.

\begin{tabular}{lccc}
\hline Index $\dagger$ & TaAMLTI & TaMATEIB & Haplotype \\
\hline$P_{\text {im }}$ & $-0.79 * *$ & $-0.4 I^{* *}$ & $-0.82^{* *}$ \\
CIATF (338) & $0.69 * *$ & $0.37^{* *}$ & $0.7 I^{* *}$ \\
CIATF (195) & $-0.46^{* *}$ & 0.02 & $-0.44^{* *}$ \\
Index gain (338) & 0.10 & 0.04 & 0.11 \\
Index gain (195) & 0.33 & 0.37 & 0.38 \\
\hline ** Significant at the & 0.01 ro
\end{tabular}

** Significant at the 0.01 probability level.

† Number in parentheses refers to the dataset used: 338 wheat genotypes used by Aguilera et al. (2016) and 195 wheat genotypes used in the present work.
TaMATE1B promoter alleles, respectively, was calculated (Table 4). Among the 195 wheat genotypes evaluated, five TaALMTI alleles and two TaMATE1B alleles were detected. For TaALMT1, the alleles V (47\%) and I (30\%) were the most frequent, whereas for TaMATE1B, the absence (90\%) of the insertion was detected in more genotypes than its presence (10\%) (Supplemental Table S1). All the top 20 most Al-resistant genotypes showed TaALMT1 alleles VI or $\mathrm{V}$ in equal proportion. The insertion in the TaMATE1B promoter was detected in 10 genotypes that are among the top 20 . When combining the alleles from both genes, nine haplotypes were detected with the allele TaMATE1B (+) not being detected along with TaALMT1 alleles II, III, and IV (Fig. 1a, b). In Fig. 1a, a positive effect of TaMATE1B (+) allele is observed for higher alleles $\mathrm{V}$ and VI, in addition to allele I (even though it is represented by only one genotype). On average, the presence of TaMATE1B superior allele (containing the insertion in the promoter region) decreased the $P_{\text {im }}$ (increased Al resistance) by 105, 138, and $259 \%$ in the presence of TaALMT1 alleles I, V, and VI, respectively (Fig. 1a). All 23 SHW lines analyzed showed only three haplotypes $[\mathrm{I}(-), \mathrm{V}(-)$, and $\mathrm{VI}(-)]$. The favorable allele of the TaMATE1B gene was not observed in any of these lines, indicating the absence of the tetraploid ancestors (Fig. 1b). The correlations showed highly significant differences $(P<$ 0.001 ) across all data while showing the efficiency and the gain obtained by comparing the $P_{\text {im }}$ with the CIATF index obtained by Aguilera et al. (2016) (Table 4). The highest correlations were obtained with haplotypes $>$ TaALMT1 > TaMATE1B. This behavior indicates that the new index did not alter the results of the correlations between CIATF and the alleles but altered the magnitude of the correlations (Table 4). Nevertheless, the new index improved the prediction of the behavior when selecting aluminum-resistant wheat genotypes. 


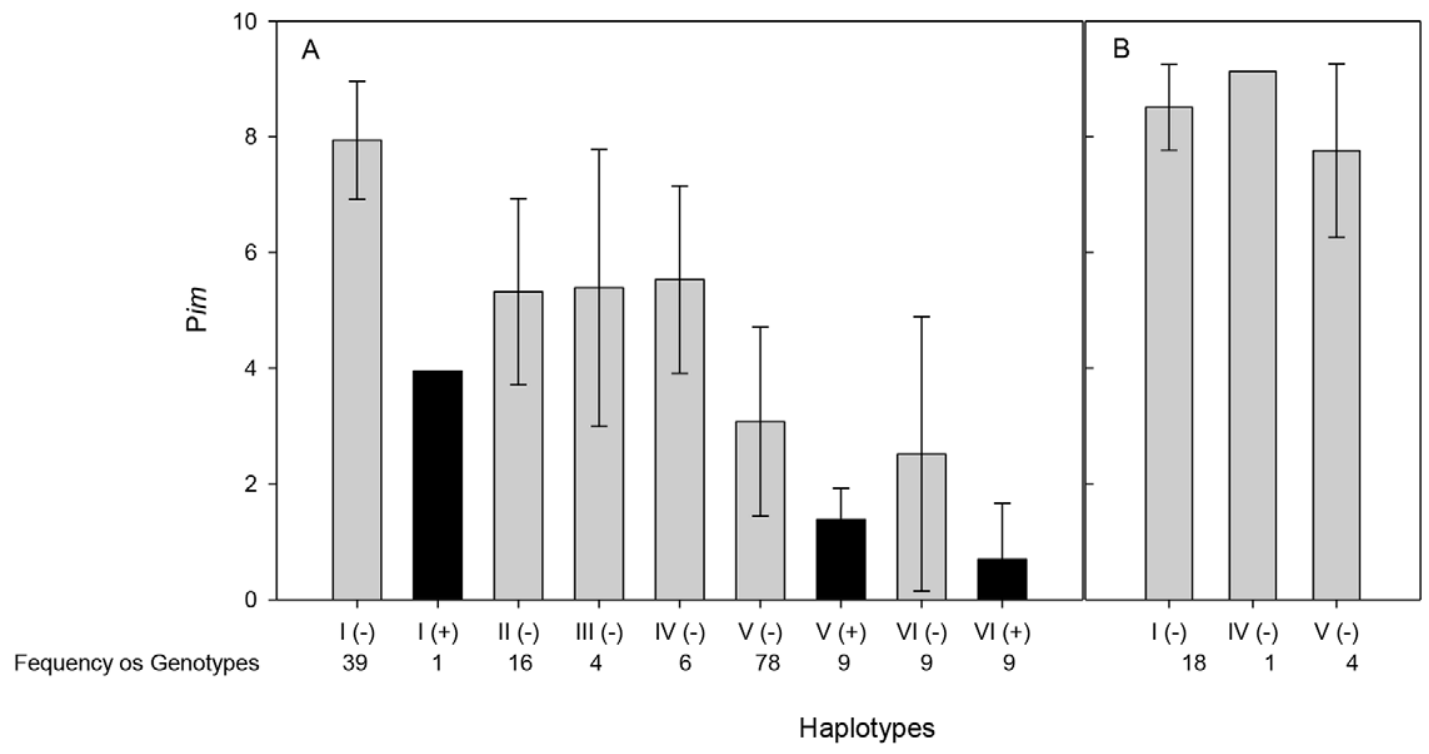

Fig. I. Effect of the TaMATEIB alleles on the $P_{\text {im }}$ index of 172 genotypes of Triticum aestivum (a) and 23 genotypes synthetic hexaploid wheat (b). Bars indicate the mean and SD of $P_{\text {im }}$ for the different haplotypes of TaAMLTI and TaMATEIB promoters (a lower $P_{\text {im }}$ value indicates greater Al resistance). The absence of the insertion in the TaMATEIB promoter (inferior allele, -) is represented by gray bars; the presence of that insertion (superior allele, + ) is indicated by black bars. I to $\mathrm{VI}$ indicate the type of the TaALMTI alleles. The frequency of genotypes in each haplotype is also shown.

\section{DISCUSSION}

The identification of the resistant genotypes and the molecular markers linked to $\mathrm{Al}$ resistance are key assets to increasing wheat performance in acidic soil. In this work, we used the information of field tests, where $\mathrm{Al}$ resistance of wheat genotypes was measured in two growing seasons and in different growth stages (Aguilera et al., 2016), to create a new selection index $\left(P_{\text {im }}\right)$ by modifying the method of Lin and Binns (1988). This new index revealed a wide diversity in plant performance in acidic soil. Additionally, the correlation of $P_{\text {im }}$ with TaALMT1 and TaMATE1B alleles improved the selection capacity of the genotypes in relation to the CIATF described previously (Aguilera et al., 2016; de Sousa, 1998; de Sousa et al., 1984).

The method initially proposed by Lin and Binns (1988) considers the developmental deviations of the cultivars in the environments and takes into account the main characteristic (many yields) and the relative response of the genotype. Its main purpose is to identify cultivars that can maintain their performance in a wide range of environments, through a statistic called $P_{\mathrm{i}}$, and to identify genotypes for favorable and unfavorable environments. This type of analysis of adaptability and stability of wheat genotypes assists the breeders in identifying new cultivars, indicating lines of wide or specific adaptation in different environments. This procedure is particularly important for wheat cultivation, especially considering the great diversity of environments to which wheat is subjected in Brazil. Also, several studies have been reported using this approach (Albrecht et al., 2007; Biudes et al., 2009; Cargnin et al., 2008; Caierão et al., 2006; Franceschi et al., 2010; Murakami et al., 2004), and most of them recommend the method of Lin and Binns (1988) as the most suitable for the species. However, no work has reported the use of this method in the selection of Al-resistant wheat. The new multivariate index, $P_{\text {im }}$, proposed in this study takes into account the response of each genotype to different environments (years) and its evaluation in different stages of development, thus modifying the method proposed by Lin and Binns (1988). We observed a gain in selection using the $P_{\text {im }}$ index. This is an advancement in our studies because, until recently, our group has used the index proposed by de Sousa et al. (1984) as modified by de Sousa (1998). This latter index is the average observation calculated from field evaluations in several stages of development of the wheat plant. The method proposed in this current study $\left(P_{\text {im }}\right.$ index) uses a more complex statistical tool to analyze the different variables observed in relation to reaction to $\mathrm{Al}$ toxicity. We found a higher correlation $(r=$ $-0.82 ; P<0.001)$ between the $P_{\text {im }}$ index and TaALMTI and TaMATE1B promoter alleles and the $\mathrm{Al}$ resistance in the field. That correlation was previously $r=0.71(P<0.001)$ when a CIATF was used (Aguilera et al., 2016).

Considering that 15 of the top 20 Al-resistant genotypes selected by the $P_{\text {im }}$ index were obtained in Brazil, and the superiority of the Brazilian materials continued to manifest as previously reported (Aguilera et al., 2016; de Sousa, 1998; Raman et al., 2008). Among the top 20 genotypes, only TaALMT1 alleles $\mathrm{V}$ and VI were observed, supporting previous results that these alleles are the best for wheat growth under $\mathrm{Al}$ toxicity (Raman et al., 2008; Sasaki et al., 2006). Half of the top 20 genotypes have the insertion in the TaMATE1B promoter (allele + ) (Fig. 1a). High $P_{\text {im }}$ index values (low Al resistance) were observed in SHW lines even with the presence of favorable $\mathrm{V}$ allele of the TaALMT1 gene (Fig. 1b). These SHWs are amphiploids obtained by crossing Triticum turgidum (AABB) and Aegilops tauschii (DD). These results agree with the $\mathrm{Al}$ sensitivity previously observed in durum wheat and SHW lines (Han et al., 2016; Ryan et al., 2010; Zhou et al., 2007). Although the TaMATE1B (+) allele has been shown to be more advantageous when combined with the inferior TaALMTI alleles (Han et al., 2016), our results from the 172 T. aestivum genotypes indicate that, on average, TaMATE1B (+) has an additive effect 
independently if the genotype contains the TaALMT1 alleles I, $\mathrm{V}$, or VI (Fig. 1a). Thus, the selection of Al-resistant wheat genotypes should be based on the superior alleles of TaALMT1 and TaMATE1B (Fig. 1a). This strategy (pyramiding Al-resistance loci) has been listed as one of the potential strategies for improving the $\mathrm{Al}$ resistance of wheat (Ryan, 2018).

There were non-Brazilian genotypes among the top 20 observed here: Giza [from Egypt with haplotype V(-)], Klein Lucero [from Argentina with haplotype VI(+)], Menceki [from Turkey with haplotype V(-)], Bet Dagan 131 [from Israel with haplotype $\mathrm{V}(+)$ ], and Maya 74 [from Guatemala with haplotype $\mathrm{V}(+)$ ]. The genealogy of these genotypes (Supplementary Table S2) showed that only the sources of resistance for Klein Lucero and Menceki were different from those of Brazil because they do not share common ancestors with Alfredo Chaves and Polyssú lines. In that case, it would be interesting to evaluate if Al resistance of these genotypes can be associated with genes other than TaALMT1 and TaMATE1B. These other genes could be introduced into Brazilian germplasm to increase $\mathrm{Al}$ resistance even further. There are several other genes associated with Al resistance that do not rely on the efflux of organic acid at the roots, and several genomic regions in wheat (different from chromosomes $4 \mathrm{~B}$ and $4 \mathrm{D}$ where TaALMT1 and TaMATE1B reside) have been associated with greater performance with Al toxicity (Froese and Carter, 2016; Navakode et al., 2014; Raman et al., 2010; Ryan et al., 2011). The introduction of new genes (different from TaALMT1 and TaMATE1B) can help to increase wheat yield, which is important to reduce Brazil's dependency on wheat importation. This is an important issue because projections by 2050 show that wheat import needs in Brazil will be higher than the current level (Weigand, 2011).

Among the genotypes selected by $P_{\text {im }}$ index as superior (top 20 among the 195 genotypes analyzed here), only three showed inferior $P_{\text {im }}$ (greater $\mathrm{Al}$ resistance) compared with Al-resistant control (IAC 5-Maringá). These genotypes were released a long time ago (Toropi in 1965, Trintecinco in 1936, BH 1146 in 1955, and IAC 5-Maringá in 1966), and they are not currently recommended for cultivation in Brazil. This means that $\mathrm{Al}$ resistance in wheat is not the major focus in the selection of new cultivars in Brazil. When considering "modern" genotypes, there are 16 cultivars in common with the 195 studied here and the 124 recommended for cultivation in Brazil in the crop season of 2018 (Franco and Evangelista, 2018) (the cultivars in common are highlighted in bold in Supplementary Table S1). Among them, the most Al-resistant cultivar is MGS1 Aliança (22nd in the ranking), showing good performance under rain-fed growth at the Brazilian Cerrado. BRS Umbu (position 38th) is the second most Al-resistant cultivar, and the remaining 14 genotypes are placed between the 49 th and 167 th positions. The fact that most of these "modern" cultivars do not show great levels of Al resistance is not an impediment for them to show good yield. Undoubtedly, the performance of these cultivars requires good management practices (e.g., lime application), although long periods are needed to ameliorate the subsoil acidity, and these practices might be costly for farmers in several countries. Thus, wheat cultivars with $\mathrm{Al}$ resistance are still an important option for farmers (Ryan, 2018).

In conclusion, the strategy proposed with $P_{\text {im }}$ index allowed the selection of superior genotypes for resistance to aluminum and confirmed that the Brazilian genotypes are main sources of resistance when compared with other genotypes from other countries. The $P_{\text {im }}$ index selected genotypes associated with the superior alleles for the genes TaALMT1 and TaMATE1B. The genotypes used as control in this work were accurately evaluated by the $P_{\text {im }}$ index. The results showed that the proposed multivariate index is a tool to be used for breeding programs aiming to select superior genotypes in environments where $\mathrm{Al}$ resistance can be advantageous, such as areas with subsoil acidity. Another great advantage of the proposed procedure is that it is based on nonparametric statistics. Therefore, the proposed index can be applied to any number of environments, traits, and genotypes without statistical assumption.

\section{ACKNOWLEDGMENTS}

This work was supported by Conselho Nacional de Desenvolvimento Científico e Tecnológico- CNPq (PNPD 560516/2010-0 grant to JPJS and Postdoctoral fellowship to J.G.A.) and Embrapa (Project "Melhoramento genético de trigo para o Brasil 2012-2016”- code number 02.11.8.001.00.03).

\section{REFERENCES}

Aguilera, J.G., J.A.D. Minozzo, D. Barichello, C.M. Fogaça, J.P. Silva, L. Consoli, and J.F. Pereira. 2016. Alleles of organic acid transporter genes are highly correlated with wheat resistance to acidic soil in field conditions. Theor. Appl. Genet. 129:1317-1331. doi:10.1007/ s00122-016-2705-3

Albrecht, J.C., E.A. Vieira, M.S. Silva, J.M.V. Andrade, P.L. Scheeren, M.G. Trindade, et al. 2007. Adaptabilidade e estabilidade de genótipos de trigo irrigado no Cerrado do Brasil Central. Pesqi. Agropecu. Bras. 42:1727-1734. doi:10.1590/S0100-204X2007001200009

Biudes, G.B., C.E. Camargo, A.W.P. Ferreira Filho, A. Pettinelli Júnior, D.E. Foltran, J.L. Castro, and J.A. Azevedo Filho. 2009. Adaptabilidade e estabilidade de linhagens diaplóides de trigo. Bragantia 68:63-74. doi:10.1590/S0006-87052009000100008

Caierão, E., M.S. Silva, P.L. Scheeren, L.J.A. del Duca, A. Nascimento, Junior., and J.L. Pires. 2006. Análise da adaptabilidade e da estabilidade de genótipos de trigo como ferramenta auxiliar na recomendação de novas cultivares. Cienc. Rural 36:1112-1117. doi:10.1590/ S0103-84782006000400011

Cargnin, A., M.A. de Souza, P.C.S. Carneiro, and V. Sofiatti. 2006. Interação entre genótipos e ambientes e implicações em ganhos com seleção em trigo. Pesqi. Agropecu. Bras. 41:987-993. doi:10.1590/ S0100-204X2006000600014

Cargnin, A., M.A. Souza, and C.M. Fogaça. 2008. Comparação de métodos de análise de adaptabilidade e estabilidade em trigo. Ceres 55:243-250.

Cargnin, A., M.A.D. Souza, V. Fronza, and C.M. Fogaça. 2009. Genetic and environmental contributions to increased wheat yield in Minas Gerais, Brazil. Sci. Agric. 66:317-322. doi:10.1590/ S0103-90162009000300006

Companhia Nacional do Abastecimento. 2018. A cultura do trigo: Análise dos custos de produção e da rentabilidade nos anos-safra 2009 a 2017. CONAB, Brasília, Brazil.

Cruz, C.D., and P.C.S. Carneiro. 2003. Modelos biométricos aplicados ao melhoramento genético II. Editora UVF, Viçosa, Brazil.

Cruz, C.D. 2013. GENES: A software package for analysis in experimental statistics and quantitative genetics. Acta Sci. Agron. 35:271-276. doi:10.4025/actasciagron.v35i3.21251

de Sousa, C.N.A. 1998. Classification of Brazilian wheat cultivars for aluminium toxicity in acid soils. Plant Breed. 117:217-221. doi:10.1111/j.1439-0523.1998.tb01929.x 
de Sousa, C.N.A., J.C.S. Moreira, L.J.A. Del Ducca, and P.L. Scheeren. 1984. Reação de cultivares estrangeiras de trigo ao crestamento em condições de campo. In: Resultados de Pesquisa do Centro Nacional de Pesquisa de Trigo. XIII Reunião Nacional de Pesquisa de Trigo, Embrapa-CNPT, Passo Fundo. p. 212-214.

Eberhart, S.A., and W.A. Russell. 1966. Stability parameters for comparing varieties. Crop Sci. 6:36-40. doi:10.2135/cropsci1966.0011183 X000600010011x

FAO. 2000. Land resource potential and constraints at regional and country levels. Land and Water Development Division, FAO, Rome, Italy.

Fischer, T., D. Byerlee, and G. Edmeades. 2014. Crop yields and global food security: Will yield increase continue to feed the world? ACIAR Monograph 158. Australian Centre for International Agricultural Research: Canberra, Australia.

Franceschi, L., G. Benin, V.S. Marchioro, T.N. Martin, R.R. Silva, and C.L. Silva. 2010. Métodos para análise de adaptabilidade e estabilidade em cultivares de trigo no estado do Paraná. Bragantia 69:797805. doi:10.1590/S0006-87052010000400004

Franco, F.A., and A. Evangelista. 2018. Informações técnicas para trigo e triticale: Safra 2018. Coodetec, Cascavel, Brazil.

Froese, P.S., and A.H. Carter. 2016. Single nucleotide polymorphisms in the wheat genome associated with tolerance of acidic soils and aluminum toxicity. Crop Sci. 56:1662-1677. doi:10.2135/ cropsci2015.10.0629

Garcia-Oliveira, A.L., P. Martins-Lopes, R. Tolrá, C. Poschenrieder, M. Tarquis, H. Guedes-Pinto, and C. Benito. 2014. Molecular characterization of the citrate transporter gene TaMATE1 and expression analysis of upstream genes involved in organic acid transport under $\mathrm{Al}$ stress in bread wheat (Triticum aestivum). Physiol. Plant. 152:441-452. doi:10.1111/ppl.12179

Han, C., S.F. Dai, D.C. Liu, Z.J. Pu, Y.M. Wei, Y.L. Zheng, D.J. Wen, L. Zhao, and Z.H. Yan. 2013. TaALMT1 promoter sequence compositions, acid tolerance, and $\mathrm{Al}$ tolerance in wheat cultivars and landraces from Sichuan in China. Genet. Mol. Res. 12:5602-5616. doi:10.4238/2013.November.18.9

Han, C., P. Zhang, P.R. Ryan, T.M. Rathjen, Z.H. Yan, and E. Delhaize. 2016. Introgression of genes from bread wheat enhances the aluminium tolerance of durum wheat. Theor. Appl. Genet. 129:729-739. doi:10.1007/s00122-015-2661-3

Kochian, L.V., M.A. Piñeros, J. Liu, and J.V. Magalhaes. 2015. Plant adaptation to acid soils: The molecular basis for crop aluminum resistance. Annu. Rev. Plant Biol. 66:571-598. doi:10.1146/ annurev-arplant-043014-114822

Lin, C.S., and M.R. Binns. 1988. A superiority measure of cultivar performance for cultivar x location data. Can. J. Plant Sci. 68:193-198. doi:10.4141/cjps88-018

Murakami, D.M., A.A. Cardoso, C.D. Cruz, and N. Bizão. 2004. Considerações sobre duas metodologias de análise de estabilidade e adaptabilidade. Cienc. Rural 34:71-78. doi:10.1590/ S0103-84782004000100011
Navakode, S., K. Neumann, B. Kobiljski, U. Lohwasser, and A. Börner. 2014. Genome wide association mapping to identify aluminium tolerance loci in bread wheat. Euphytica 198:401-411. doi:10.1007/ s10681-014-1114-4

Raman, H., P.R. Ryan, R. Raman, B.J. Stodart, K. Zhang, P. Martin, et al. 2008. Analysis of TaALMT1 traces the transmission of aluminum resistance in cultivated common wheat (Triticum aestivum L.). Theor. Appl. Genet. 116:343-354. doi:10.1007/s00122-007-0672-4

Raman, H., B. Stodart, P.R. Ryan, E. Delhaize, L. Emebiri, R. Raman, N. Coombes, and A. Milgate. 2010. Genome-wide association analyses of common wheat (Triticum aestivum L.) germplasm identifies multiple loci for aluminium resistance. Genome 53:957-966. doi:10.1139/G10-058

Ryan, P.R., H. Raman, S. Gupta, T. Sasaki, Y. Yamamoto, and E. Delhaize. 2010. The multiple origins ofaluminium resistance in hexaploid wheat include Aegilopstauschii and more recent cis mutations to TaALMT1. Plant J. 64:446-455. doi:10.1111/j.1365-313X.2010.04338.x

Ryan, P.R., S.D. Tyerman, T. Sasaki, T. Furuichi, Y. Yamamoto, W.H. Zhang, and E. Delhaize. 2011. The identification of aluminiumresistance genes provides opportunities for enhancing crop production on acid soils. J. Exp. Bot. 62:9-20. doi:10.1093/jxb/erq272

Ryan, P.R. 2018. Assessing the role of genetics for improving the yield of Australia's major grain crops on acid soils. Crop Pasture Sci. 69:242264. doi:10.1071/CP17310

Sasaki, T., Y. Yamamoto, B. Ezaki, M. Katsuhara, S.J. Ahn, P.R. Ryan, E. Delhaize, and H. Matsumoto. 2004. A wheat gene encoding an aluminum-activated malate transporter. Plant J. 37:645-653. doi:10.1111/j.1365-313X.2003.01991.x

Sasaki, T., P.R. Ryan, E. Delhaize, D.M. Hebb, Y. Ogihara, K. Kawaura, et al. 2006. Sequence upstream of the wheat (Triticum aestivum L.) ALMT1 gene and its relationship to aluminum resistance. Plant Cell Physiol. 47:1343-1354. doi:10.1093/pcp/pcl002

Tovkach, A., P.R. Ryan, A.E. Richardson, D.C. Lewis, T.M. Rathjen, S. Ramesh, et al.2013. Transposon-mediated alteration of TaMATE1B expression in wheat confers constitutive citrate efflux from root apices. Plant Physiol. 161:880-892. doi:10.1104/pp.112.207142

von Uexküll, H.R., and E. Mutert. 1995. Global extent, development and economic impact of acid soils. Plant Soil 171:1-15. doi:10.1007/ BF00009558

Weigand, C. 2011. Wheat import projections towards 2050. US Wheat Associates, Arlington, VA.

Yang, J.L., W. Fan, and S.J. Zheng. 2019. Mechanisms and regulation of aluminum-induced secretion of organic acid anions from plant roots. J. Zhej. Univ. 20:513-527. doi:10.1631/jzus.B1900188

Zhou, L.L., G.H. Bai, B. Carver, and D.D. Zhang. 2007. Identification of new sources of aluminum resistance in wheat. Plant Soil 297:105118. doi:10.1007/s11104-007-9324-3 